\title{
Pengaruh citra merek (Brand Image) terhadap loyalitas merek produk lipstik wardah pada global kosmetik Kecamatan Tualang Kabupaten Siak
}

\author{
Nadia Vega $^{1^{*}}$, Annisa Mardatillah $^{2}$ \\ ${ }^{1,2}$ Administrasi Bisnis, Universitas Islam Riau \\ ${ }^{*}$ Correspondent email : nadiavega0303@gmail.com
}

\begin{abstract}
This study aims to determine the effect of brand image on brand loyalty of Wardah lipstick products in global cosmetics, Tualang District, District. In this study, for the brand, image variable uses indicators, namely attributes, benefits, overall evaluation, while for brand loyalty variables using indicators, namely measuring behavior, measuring costs, measuring satisfaction, brand liking, and commitment. The type in this study uses a descriptive type of research using quantitative methods because this study explains the relationship between the Brand Image $(X)$ variable and the Brand Loyalty variable $(Y)$. The sampling technique used is a purposive sampling technique or subjectively aimed sample. This research method determines respondents to be used as samples because they have specific criteria for 100 respondents. Data collection techniques are by distributing questionnaires, interviews, observations, and documentation. The data analysis technique used is simple linear analysis.
\end{abstract}

Keywords: Brand Image, Brand Loyalty, Cosmetic, Halal

\section{PENDAHULUAN}

Industri kosmetik menjadi salah satu industri yang sangat berkembang pesat didukung dengan kemajuan ilmu pengetahuan dan teknologi canggih. Saat ini produk kecantikan dan kosmetik, telah mengalami banyak perubahan dengan dikeluarkannya inovasi-inovasi mutakhir yang sesuai dengan kebutuhan dan keinginan konsumen. Pola hidup yang terus berkembang di zaman modern membuat setiap orang berkeinginan tampil cantik dan menarik menunjang setiap aktivitasnya. Kosmetik adalah salah satu kebutuhan yang menjadi kewajiban untuk para wanita mulai usia remaja hingga dewasa yang digunakan dalam kegitan sehari-hari. Wanita selalu ingin terlihat sempurna dan menarik disetiap waktu. Oleh karena itu, salah satu cara untuk menunjang penampilan yang menarik adalah dengan menggunakan produk kecantikan sebagai penunjang penampilan.

Lipstik Wardah menjadi pelopor untuk kategori perawatan pribadi produk lipstik halal yang sangat di minati di kalangan wanita selain karena produk yang sudah berbadan POM dan berlebel halal cocok untuk kaum wanita yang ada diIndonesia dengan mayoritasnya beragama muslim. Kemasan dan warna lipstik yang bervariasi dapat dilihat dari persentase pertumbuhan penjualan produk lipstik wardah yang paling tinggi untuk kategori lipstik khusususnya di Global Kosmetik Kecamatan Tualang Kabupaten Siak tahun 2019. Produk lipstik wardah selalu menonjpolkan konsep lebel halal pada setiap iklan yang dilakukan. Wardah adalah produk kosmetik yang mendapatkan serifikasi halal yang pertama kali di Indonesia. Kosmetik Wardah mengantongi sertifikasi halal dari LP POM MUI, bahkan di tahun 2012, Wardah mendapatkan Anugerah Halal Award dari MUI dan Kementerian Agama.

Kategori wanita remaja yaitu mahasiswa yang merupakan objek yang sangat memperhatikan penampilan dalam menundukung kegiatanan sehari-hari, terkadang sulit untuk memilih memakai produk kosmetik dengan harga murah dan terjangkau tetapi kualitas yang diterima memuaskan. Dalam kaitannya dengan perilaku remaja pada kategori mahasiswa sebagai konsumen merupakan target besar bagi pemasar, tidak hanya karena remaja merupakan konsumen yang menguntungkan, namun juga karena pola konsumsinya yang mengikuti perkembangan zaman. Walaupun tidak dapat diungkiri sebagian besar remaja tidak memiliki penghasilan tetap, tetapi ternyata mereka memiliki pengeluaran yang cukup besar. Ada remaja belum memiliki pekerjaan yang tetap karena masih menempuh jenjang pendidikan. 


\section{SYNERGY}

Vol 1, No 2, Oktober 2021, p. 38-44

Jurnal Bisnis dan Manajemen

Remaja pada kategori mahasiwa menjadi target karena remaja memandang segala sesuatunya masih bergantung pada emosinya sehingga menentukan pandangannya terhadap suatu objek psikologi dan emosi remaja pada umumnya belum stabil. Selain itu, jumlah populasi remaja dan fakta bahwa remaja kurang terampil dalam mengelola keuangan dari pada kelompok usia lainnya yang menyebabkan remaja menjadi target menarik bagi pelaku bisnis terutama pada bisnis produk kosmetik perawatan pribadi. Dan yang dapat dikategori wanita remaja diantara remaja awal, yang dimulai usia 12 sampai 15 tahun, remaja tengah yaitu usia 15 sampai 18 tahun, dan remaja akhir atau biasanya dikenal dengan istilah anak muda usia 18 sampai 21 yang tidak lain dalam kategori mahasiswa.

Dalam menggunakan produk kecantikan biasanya konsumen khususnya wanita apalagi mahasiswa selalu menggunakan produk yang sesuai dengan tipe kulitnya. Persaingan di dunia industri perawatan dan kosmetik yang semakin berkembang dengan cepat. Hal ini dapat dilihat dari banyaknya jenis kosmetik yang beredar di pasaran, baik yang diproduksi oleh dalam negeri maupun dari luar negeri yang membuat semakin ketatnya daya saing. Keberagaman produk kecantikan yang ada di pasar, ternyata mempengaruhi sikap seseorang dalam memilih produk kecantikan yang sesuai dengan tipe kulitnya, dengan melihat risiko yang akan terjadi ataupun efeknya yang berbahayakan bagi kesehatan kulit.

Merek dijadikan sebagai hal utama untuk mengenali suatu produk tetapi sebagai konsumen bukan hanya melihat dari merek produk saja melainkan melihat baik tidak nya suatu produk dilihat juga dari manfaat produk, bentuk produk, kualitas produk, dan harga produknya. Dengan membeli produk yang bermerek dan menjanjikan serta sesuai dengan ekspetasi, konsumen pasti merasakan manfaat produk yang diingikan oleh konsumen. Pengunaan kosmetik adalah kebutuhan yang sudah menjadi prioritas mulai dari kebutuhan dasar, kebutuhan pedamping, dan kebutuhan mewah. Oleh karena itu perlu bagi setiap perusahaan untuk mempertahankan citra merek untuk dapat bersaing dengan pasar. Dengan selalu membuat inovasi-inovasi baru pada produk dan menjamin kualitasnya. Dapat dilihat dari permintaan akan banyaknya kalangan wanita apalagi remaja yang membeli produk lipstik maka akan mempengaruhi peningkatan penjualan pada produk kosmetik khususnya pada produk lipstik.

Loyalitas merek menunjukkan adanya ikatan pelanggan dengan merek tertentu dan ditandai adanya pembelian ulang dari pelanggan (Aaker, 2009; Sciffman \& Kanuk, 2015; Moriuchi \& Takahashi, 2016). Loyalitas merek mencerminkan loyalitas pelanggan pada merek tertentu. Loyalitas merek merupakan suatu kondisi dimana konsumen memiliki sikap yang positif terhadap suatu merek tertentu, memiliki komitmen terhadap merek, dan memiliki kecenderungan untuk terus-meneruskan memmbelinya di masa kini maupun dimasa yang akan datang (Hurriyati, 2005). Dengan adanya konsumen yang loyal pada merek sangat diperlukan bagi perusahaan agar perusahaan dapat bertahan hidup dan bisa berkembang pesat serta mampu bersaing dipasar. Loyalitas dapat diartikan sebagai suatu komitmen yang mendalam untuk melakukan pembelian ulang produk atau jasa yang menjadi preferensinya secara konsisten pada masa yang akan datang dengan membeli ulang merek produk atau jasa yang sama meskipun ada pengaruh situasi dan usaha pemasaran yang dapat menimbulkan perilaku keberalihan terhadap merek lain

Citra merek merupakan pengamatan dan kepercayaan yang digenggam konsumen yang dicerminkan atau dalam ingatan konsumen yang dapat membentuk suatu persepsi pasar akan merek tersebut (Hart \& Stapletton, 2005). Perusahaan harus memiliki produk yang memiliki citra merek yang baik untuk mampu bersaing dengan industri kosmetik lainnya dan produk yang ditawarkan bisa menjadi produk yang akan selalu dibeli dimasa sekarang maupun dimasa yang akan datang (Fandy Tjiptono., 2005). Menurut hasil penelitian sebelumnya dinyatakan bahwa citra merek memberikan pengaruh pada loyalitas merek (Kotler, 2016; Han, et al 2018). Selanjutnya diperkuat oleh penelitian (Variano, 2017; Faizal \& Nurjanah, 2019) bahwa perusahaan yang memiliki pelanggan loyal dapat menghambat pesaing dalam memutuskan pembelian. Disisi lain Tingkir (2014) dalam penelitiannya menunjukkan bahwa loyalitas merek adalah ukuran yang menunjukkan hubungan pelanggan pada suatu merek bahkan dapat mendatangkan konsumen loyal yang baru.

\section{METODE PENELITIAN}

Pada penelitian ini menggunakan tipe penelitian kuantitatif yang menurut Sugiyono (2017) metode kuantitaf adalah metode penelitian yang berlandaskan pada filsafat postpositivisme, digunakan untuk meneliti pada populasi atau sampel tertentu, pengumpulan data menggunakan instrumen penelitian, analisis data bersifat kuantitatif atau statistik, dengan tujuan untuk menguji hipotesis yang telah ditetapkan.

Dalam penyusunan instrumen atau alat pengumpulan data, variabel-variabel yang menjadi acuan utama peneliti dalam menyusun angket. Adapun cara yang digunakan dalam menganalisa data adalah analisis kolerasi dan analisi regresi. 
Sementara itu, penelitian ini juga menggunakan penelitian deskritif yang merupakan suatu bentuk penelitian yang ditujukan untuk mendeskripsikan atau menggambarkan fenomena-fenomena yang ada, baik fenomena alamiah maupun rekayasa manusia.

\section{Populasi}

Populasi adalah wilayah generalisasi yang terdiri atas objek atau subjek yang mempunyai kualitas dan karakterisrik tertentu yang ditetapkan oleh peneliti untuk dipelajari dan kemudian ditarik kesimpulan (Sugiyono., 2017).

Populasi dalam penelitian ini adalah konsumen yang pernah melakukan pembelian terhadap produk lipstik wardah pada global kosmetik kecamatan tualang kabupaten siak yang jumlahnya tidak diketahui dan dapat dikatakan dalam kategori tidak terhinnga.

Karena populasi dari penelitian ini adalah semua konsumen yang membeli produk lipstik wardah pada global kosmetik kecamatan tualang kabupaten siak dan jumlahnya tidak diketahui secara pasti, maka digunakan penentuan jumlah sampel untuk populasi tidak terhingga.

\section{Sampel}

Menurut Sugiyono (2017) sampel adalah bagian dari jumlah dan karakteristik yang dimiliki oleh populasi tersebut. Bila populasi besar, peneliti tidak mungkin mengambil semua untuk penelitian misal karena terbatasnya dana, tenaga dan waktu, maka peneliti dapat menggunakan sampel yang diambil dari populasi itu. Diperoleh sampel minimal sebesar 96,6 yang dibulatkan keatas menjadi 97 sampel. Namun jumlah sampel yang digunakan dalam penelitian ini nantinya adalah sebanyak 100 responden.

Tabel 1. Populasi dan Sampel Penelitian

\begin{tabular}{ccccc}
\hline No & $\begin{array}{c}\text { Sumber } \\
\text { Informasi }\end{array}$ & $\begin{array}{c}\text { Teknik yang } \\
\text { digunakan }\end{array}$ & Populasi & Sampel \\
\hline 1 & Konsumen & $\begin{array}{c}\text { Penyebaran } \\
\text { kuesioner } \\
\text { online } \\
2\end{array}$ & $\begin{array}{c}\text { Tidak } \\
\text { terhingga } \\
(\infty)\end{array}$ & 100 \\
& Mawancara & 1 & 1 \\
& & & $\begin{array}{c}\text { Tidak } \\
\text { Terhingga } \\
(\infty)\end{array}$ & 100 \\
& & & & \\
\hline
\end{tabular}

Sumber : Data Diolah, 2020

\section{Jenis dan Sumber Data}

Jenis dan sumber penelitian yang digunakan oleh penulis data primer dan data Sekunder.

\section{HASIL DAN PEMBAHASAN}

\section{Uji Hipotesis}

Berdasarkan hasil penelitian yang telah dilakukan melalui kuisioner kepada para responden melalui variabel Citra Merek dan Loyalitas Merek maka diuji kelayakan dari masing-masing variabel dan indikator-indikator tersebut atau dapat juga dikatakan sebagai pengujian kualitas data yang bertujuan untuk menentukan batas-batas kebenaran ketetapan alat ukur (kuisioner) suatu kebenaran ketetapan indikator variabel penelituan dapat dilakukakan dengan cara sebagai berikut:

\section{Uji Validasi}

Didalam penelitian ini, uji coba dilakukan terhadap 100 responden. Perhitungan uji validasi dilakukan dengan program SPSS versi 22. Uji signifikan dilakukan dengan membandingkan nilai $r$ hitung (untuk menghitung tiap butir dapat dilihat pada lampiran output Cronbach Alpha pada kolom (Correcetec Item- Total Corrlation) dengan $\mathrm{r}$ table untuk degree of freedom $(\mathrm{df})=\mathrm{n}-2$, dalam hal ini $\mathrm{n}$ adalah jumlah sample. Dalam penelitian ini jumnlah sampel $\mathrm{n}$ adalah $(100)=100$. Maka besarnya df dapat dihitung dengan $100-2=98$. Jadi besarnya $\mathrm{df}=98$ dan alpha 0,05 dapat $\mathrm{r}$ tabel $=0,196$ jika $\mathrm{r}$ hitung lebih besar dari $\mathrm{r}$ tabel dan nilai positif maka butir atau pertanyaan atau indikator tersebut dinyatakan valid. 
Tabel 2. Hasil Uji Validasi Instrumen Penelitian

\begin{tabular}{|c|c|c|c|}
\hline Item & $\begin{array}{l}\text { Corrected Item Total } \\
\text { Correlations (r hitung) }\end{array}$ & $\mathrm{r}$ table $\mathrm{a}=0,05$ & Keterangan Hasil \\
\hline $\mathrm{X} 1$ & 0,696 & 0,196 & Valid \\
\hline $\mathrm{X} 2$ & 0,664 & 0,196 & Valid \\
\hline $\mathrm{X} 3$ & 0,612 & 0,196 & Valid \\
\hline $\mathrm{X} 4$ & 0,756 & 0,196 & Valid \\
\hline $\mathrm{X} 5$ & 0,648 & 0,196 & Valid \\
\hline $\mathrm{X} 6$ & 0,692 & 0,196 & Valid \\
\hline $\mathrm{X} 7$ & 0,723 & 0,196 & Valid \\
\hline $\mathrm{X} 8$ & 0,537 & 0,196 & Valid \\
\hline X9 & 0,543 & 0,196 & Valid \\
\hline Y1 & 0,488 & 0,196 & Valid \\
\hline Y2 & 0,664 & 0,196 & Valid \\
\hline Y3 & 0,656 & 0,196 & Valid \\
\hline Y4 & 0,601 & 0,196 & Valid \\
\hline Y5 & 0,625 & 0,196 & Valid \\
\hline Y6 & 0,760 & 0,196 & Valid \\
\hline Y7 & 0,757 & 0,196 & Valid \\
\hline Y8 & 0,520 & 0,196 & Valid \\
\hline Y9 & 0,561 & 0,196 & Valid \\
\hline Y10 & 0,669 & 0,196 & Valid \\
\hline Y11 & 0,680 & 0,196 & Valid \\
\hline Y12 & 0,657 & 0,196 & Valid \\
\hline Y13 & 0,451 & 0,196 & Valid \\
\hline Y14 & 0,569 & 0,196 & Valid \\
\hline Y15 & 0,544 & 0,196 & Valid \\
\hline
\end{tabular}

Sumber : Data Olahan Penelitian, 2021

Hasil uji validasi penelitian ini masing-masing variabel Citra Merek dan Loyalitas Merek r-hitung > r-tabel yaitu df- $2=98$ deangan taraf signifikan $5 \%$ adalah 0,196 yang didapat dari tabel $\mathrm{R}$ dengan tingkat signifikankansi untuk uji dua arah sehingga dapat dikatakan semua konsep pengukuran variabel Citra Merek dan Loyalitas Merek ini adalah valid.

\section{Uji Reabilitas}

Uji reabilitas bertujuan untuk menguji suatu kuisioner apakah sudah realibel (konsisten) jika diuji secara berulang -ulang. Adapun dasar pengambilan keputusan dalam uji reabilitas yaitu jika nilai cronbach alpha $>0.06$. Maka dapat dikatakan realibel karena Citra Merek memiliki nilai cronbac alpha sebesar 0,825 dan Loyalitas Merek memiliki nilai crobanch alpha sebesar 0,880 dan dapat diartikan bahwa pengujian data ini realibel (konsisten).

Tabel 3. Reliability Statistics Citra Merek

\begin{tabular}{ccc}
\hline Cronbach's Alpha & $\begin{array}{c}\text { Cronbach's Alpha Based on } \\
\text { Standardized Items }\end{array}$ & N of Items \\
\hline .825 & .832 & 9 \\
\hline
\end{tabular}

Sumber : Data Olahan Penelitian, 2021

Tabel 4. Reliability Statistics Loyalitas Merek

\begin{tabular}{ccc}
\hline Cronbach's Alpha & $\begin{array}{c}\text { Cronbach's Alpha Based on } \\
\text { Standardized Items }\end{array}$ & N of Items \\
\hline .880 & .890 & 15 \\
\hline
\end{tabular}

Sumber : Data Olahan Penelitian, 2021

\section{Uji Koefisien Regresi}


Untuk membuktikan besar mempengaruhi baik secara parsial maupun digunakan model persamaan $\mathrm{Y}=\mathrm{a}+\mathrm{bx}$. Regresi linear sederhana didasarkan pada hubungan fungsional ataupun kausal satu variabel dependen dan variabel independen.

$\mathrm{X}$.

Berdasarkan hasil perhitung diperoleh persaamaan regresi linier sederhana adalah $\mathrm{Y}=16,541+0,698$

Dilihat dari persamaan Dilihat dari persamaan regresi linier sederhana diatas, maka dapat diuraikan bahwa nilai, $a=16,541$ menunjukan jika variabel Citra Merek adalah konstanta (tetap) maka besar Loyalitas Merek Global Kosmetik Kecamatan Tualang Kabupaten Siak adalah 16,541 sedangkan koefesien linier sederhana adalah 0,698 artinya setiap perubahan variabel X (Citra Merek) berubah sebesar satuan-satuan variabel Y (Loyalitas Merek) akan berubah sebesar 0,698. Misalnya jika Citra Merek naik 10\% maka Loyalitas Merek akan naik sebesar 6,98\%.

\section{Menentukan Koefesien Korelasi}

Koefisien Korelasi (r) bertujuan untuk melihat kuat atau lemahnya hubungan antara variable independen dengan variable dependent. Nilai koefesien korelasi (r) sebesar 0,698. Ini berarti kerataan hubungan variabel bebas Citra Merek dengan variable terikat Loyalitas Merek dikategorikan kuat karna pada range 0,60-0,779 Arah hubungan yang pada angka 0,698 menunjukan Citra Merek akan membuat Loyalitas Merek semakin baik.

\section{Menentukan Koefisien Determinasi}

Uji Koefisien destriminasi atau R Squere $\left(R^{2}\right)$ bertujuan untuk melihat seberapa besar kontribusi variable indenpenden terhadap variable dependen.

Tabel 5. Hasil Perhitungan Koefisien Destriminasi (Model Summary)

\begin{tabular}{lcccr}
\hline \multicolumn{4}{c}{ Model Summary } \\
\hline Model & $\mathrm{R}$ & R Square & Adjusted R Square & $\begin{array}{c}\text { Std. Error of the } \\
\text { Estimate }\end{array}$ \\
1 &, $698^{\mathrm{a}}$ &, 488 &, 482 & 3,70272 \\
a. Predictors: (Constant), Citra Merek & & & \\
\hline
\end{tabular}

Sumber : Data Olahan Penelitian, 2021

Dari tabel 5 diperoleh nilai koefisien destriminasi atau R Squeare $\left(\mathrm{R}^{2}\right)$ diperoleh sebesar 0,488 atau 48,8\%. Maka dari itu hal ini menunjukan bahwa variable citra merek terbukti mempengaruhi variabel loyalitas merek pada Global Kosmetik Kecamatan Tualang Kabupaten Siak sebesar 48,8\% sedangkan sisanya sebesar $52 \%$ yang dipengaruhi oleh variable lain tetapi tidak di bahas dalam penelitian ini.

\section{Uji t}

Teori yang mendukung menurut Ghozali (2012) uji t digunakan untuk mengetahui bagaimana tingkat signifikan pengaruh variable bebas Citra Merek (X) terhadap variable terkiat Loyalitas Merek (Y), untuk uji $t$ dengan $t$ hitung apakah, signifikan apabila $t$ hitung $>t$ table. Berdasarkan hasil perhitungan dengan SPSS diatas maka, dapat disimpulkan bahwa: $\mathrm{DF}=\mathrm{n}-\mathrm{k}-1=100-1-1=98 \mathrm{a}=0,05$ maka $(0,05: 98)$ adalah 0,196 .

Tabel 6. Koefisien Parsial Citra Merek Terhadap Loyalitas Merek Produk Lipstik Wardah

\begin{tabular}{ccc} 
Variabel & t-hitung & $\mathrm{t}-$ table \\
\hline Citra Merek & 7,479 & 1,196 \\
\hline
\end{tabular}

Sumber: Data Penelitian, 2021.

Dengan demikian untuk variable Citra merek, $\mathrm{t}$ - hitung adalah 7,479 denagan t-table yaitu $(0,05: 98)$ adalah 1,196 karena $t$ - hitung $(7,479)>$ dari t-tabel $(1,196)$ maka Ho di tolak H1 diterima. Dengan variabel Citra Merek berpengaruh signifikan terhadap Loyalitas Merek pada Global Kosmetik Kecamatan Tualang Kabupaten Siak. 
Hasil penelitian ini sejalan dengan pemikiran (Faizal \& Nurjanah, 2019; Tingkir, 2014) bahwa kesetiaan konsumen terhadap suatu produk karena persepsi baiknya terhadap suatu merek produk tertentu. Jumlah merek yang dibeli paling banyak pada global kosmetik yaitu lipstik wardah walaupun banyak produk pesaing terbukti dari banyak rekomendasi dari orang terdekat untuk pemakaian lipstik wardah dan banyak juga konsumen yang membeli lipstik wardah padahal banyak lipstik pesaing yang sejenis tapi kurang menonjolkan lebel halal dan tidak cocok untuk tipe kulitnya. Persentase pembelian produk lipstik wardah tidak dapat diragukan lagi terbukti dari banyaknya konsumen yang membeli produk lipstik wardah dibandingkan produk lipstik pesaing yang sama jenisnya karena wardah sudah menjadi pelopor lipstik yang sudah dipercaya wanita muslim.

Produk lipstik wardah menurut tanggapan responden dari atribut produk lipstik wardah diterima konsumen melalui citra merek desain kemasan dari produk lipstik wardah sangat styles dan mudah di bawa kemana-mana terbukti adanya, sehingga menarik konsumen untuk membelinya. Selanjutnya dilihat dari manfaat produk lipstik wardah melalui bahan yang terkandung di lipstik wardah sesuai dengan yang dijanjikan responden merasakan manfaat yang dinginkan dari pengunaan lipstik wardah setelah pemakaian lipstik wardah tapi belum sepenuhnya dirasakan karna produk lipstik yang sejenis juga sama seperti itu.

Nilai kepuasan yang diterima konsumen setelah pemakain produk lipstik wardah sesuai dengan kebutuhan tetapi juga terkadang bisa digantikan dengan produk lipstik lain yang sejenis jika merasa bosan atau ingin mencoba yang lain. Nilai kepuasan yang diterima konsumen setelah pemakain produk lipstik wardah sesuai dengan kebutuhan tetapi juga terkadang bisa digantikan dengan produk karena terkadang diselingi dengan produk lipstik lain. Pengukuran terhadap kepuasan maupun ketidakpuasan pelanggan suatu merek merupakan indikator penting dari loyalitas merek (Kim et al, 2018). Bila ketidakpuasan pelanggan terhadap suatu merek rendah, maka pada umumnya tidak cukup alasan bagi pelanggan untuk beralih mengkonsumsi merek lain. Selain itu komitmen konsumen terbentuk karena adanya rasa kepercayaan atas merek lipstik wardah.

Loyalitas merek konsumen terhadap lipstick wardah dilihat melalui komitmen konsumen adanya keinginan melakukan pembelian ulang oleh konsumen karna produk lipstik wardah sesuai dengan kebutuhan konsumen dan konsumen merasa puas setelah pemakaian produk lipstik wardah pada global kosmetik. Hasil penelitian ini sejalan dengan penelitian Chaudhuri \& Holbrook (2001) dan Moriuchi \& Takahashi (2016) bahwa perilaku pembelian berulang dari sebuah merek menunjukkan sikap tingkat komitmen yang diasosiasikan pada suatu merek. Hal ini selanjutnya dapat dilihat melalui hasil penelitian terkait rasa kepercayaan konsumen pada lipstik wardah terbentuk rasa kepercayaan yang baik karena responden merasakan manfaat dari kualitas produk lipstik wardah, tidak mengecewakan sesuai dengan kebutuhan konsumen.

\section{KESIMPULAN}

Hasil penelitian ini disimpulkan bahwa Citra Merek berpengaruh terhadap Loyalitas Merek lipstik wardah pada Global Kosmetik Kecamatan Tualang Kabupaten Siak. Lipstik wardah memberikan nilai kepuasan bagi konsumen untuk terus komitmen memilih lipstick wardah dan tidak memiliki cukup alasan untuk beralih pada merek lipstik lain meskipun sesekali terkadang untuk variasi ingin mencoba pada produk sejenis. Rasa kepercayaan muncul dari menggunakan lipstik wardah ini karena lebel halal yang tercantum pada kemasan lipstik merek wardah bagi mayoritas dengan keyakinan Islam. Label halal dan kualitas lipstik wardah menjadi faktor kekuatan yang melahirkan kepercayaan konsumen sehingga menjadi loyal untuk terus melakukan pembelian ulang.

\section{UCAPAN TERIMAKASIH}

Terimakasih kepada semua pihak yang telah membantu dalam penelitian ini.

\section{DAFTAR PUSTAKA}

Aaker, D. A. (2009). Manajemen Ekuitas Merek. Spektrum.

Chaudhuri, A., and Holbrook, M. (2001). The chain of effects from brand trust and brand affect to brand performance. The role of brand loyalty. Journal of Marketing., 37(11), 1762-1800.

Faizal, H., \& Nurjanah, S. (2019). Pengaruh Persepsi Kualitas Dan Citra Merek Terhadap Loyalitas Pelanggan Dengan Kepercayaan Pelanggan Dan Kepuasan Pelanggan Sebagai Variabel Antara. Jurnal Riset Manajemen Dan Bisnis (JRMB) Fakultas Ekonomi UNIAT, 4(2), 307-316. 
SYNERGY

Jurnal Bisnis dan Manajemen

https://doi.org/10.36226/jrmb.v4i2.271

Fandy Tjiptono. (2005). Brand management \& Strategi. ANDI : Yogyakarta.

Ghozali, I. (2012). Aplikasi Analisis Multivariate dengan Program IBM SPSS. Universitas Diponegoro.

Han, H., Nguyen, H. N., Song, H., Chua, B. L., Lee, S., \& Kim, W. (2018). Drivers of brand loyalty in the chain coffee shop industry. International Journal of Hospitality Management, 86-97.

Hart, A. N \& Stapletton, J. (2005). Kamus Marketing. Jakarta: BumiAksara.

Hurriyati, R. (2005). Bauran Pemasaran dan Loyalitas. Alfabeta.

Kim, S. S., Choe, J. Y. J., \& Petrick, J. F. (2018). The effect of celebrity on brand awareness, perceived quality, brand image, brand loyalty, and destination attachment to a literary festival. Journal of Destination Marketing \& Management, 9, 320-329.

Kotler, P. and K. L. K. (2016). Marketing Managemen, 15th Edition,. Pearson Education,Inc.

Moriuchi, E., \& Takahashi, I. (2016). Satisfaction trust and loyalty of repeat online consumer within the Japanese online supermarket trade. Australasian Marketing Journal (AMJ), 24(2), 146-156.

Sciffman \& Kanuk. (2015). Consumer Behavior. 11 th Edition. Global Edition.

Sugiyono. (2017). Metode Penelitian Kuantitatif, Kualitatif, dan R\&D. Bandung : Alfabeta, CV.

Tingkir, C. F. (2014). Pengaruh Identitas Merek Terhadap Loyalitas Merek Melalui Citra Merek Dan Kepercayaan Merek Toyota. Jurnal Manajemen Pemasaran, 8(2), $62-69$. https://doi.org/10.9744/pemasaran.8.2.62-69

Variano, V. (2017). Pengaruh Citra Merek, Harga, dan Kualitas Layanan terhadap Loyalitas Merek Konsumen Kereta Api. AGORA, 5(3). 